\title{
Effect of Preparation Method on Chemical Property of Different Thai Rice Variety
}

\author{
Cahyuning Isnaini ${ }^{1}$, Pattavara Pathomrungsiyounggul ${ }^{2}$, Nattaya Konsue ${ }^{1{ }^{*}}$ \\ ${ }^{1}$ Food Science and Technology Program, School of Agro-Industry, Mae Fah Luang University, Muang, Chiang Rai 57100, Thailand \\ ${ }^{2}$ Faculty of Agro-Industry, Chiang Mai University, Muang, Chiang Mai 50100, Thailand \\ *Corresponding author: nattaya.kon@mfu.ac.th
}

Received January 15, 2019; Revised February 20, 2019; Accepted March 19, 2019

\begin{abstract}
Improving benefits and reducing risk of staple food consumption are of interest among researchers nowadays. Rice is the major staple foods consumed in Asia. It has been reported that rice consumption has a positive association with the risk of chronic diseases. The effects of rice variety and preparation process on chemical characteristics of rice were investigated in the current study. Three Thai rice varieties, Khao Dok Mali 105 (KDML 105), Sao Hai (SH) and Riceberry (RB), underwent parboiling or non-parboiling as well as polishing or nonpolishing prior to chemical property analysis. It was found that parboiling process possessed greater content of mineral as indicated by ash content as well as fiber and total phenolic content (TPC) and 2,2-diphenyl-1picrylhydrazyl (DPPH) radical scavenging activity when compared to non-parboiling treatments, whereas the reduction in amylose and TAC content, GI value and starch digestibility were observed in this sample. On the other hand, polishing process led to reduction in ash, amylose, fiber, TPC and TAC content and DPPH values. GI value and starch digestibility of non-parboiled rice were lowest in SH, RB and KDML 105, respectively. However, with parboiling treatment, GI values among rice varieties were not significantly different. It can be concluded that natural composition of each rice variety is different and it affects human health. However, preparation process can alter the chemical property of rice as well as influence health benefit of rice.
\end{abstract}

Keywords: gac, glycemic index, parboil, rice

Cite This Article: Cahyuning Isnaini, Pattavara Pathomrungsiyounggul, and Nattaya Konsue, "Effect of Preparation Method on Chemical Property of Different Thai Rice Variety." Journal of Food and Nutrition Research, vol. 7, no. 3 (2019): 231-236. doi: 10.12691/jfnr-7-3-8.

\section{Introduction}

Rice is the staple food that consumed more than half of population in the world. For this reason, the balance of benefit-risk of rice consumption is imperative. It has been reported that rice consumption exhibits a positive association with the risk of many chronic diseases such as type 2 diabetes and coronary heart disease [1]. Glutinous rice usually has high glycemic index (GI) implying that it causes rapidly increase in blood sugar level hence high in diabetes risk. High amylose content rice, on the other hand, has low GI value due to the formation of complexes between amylose and lipids during cooking and, therefore, less accessible to enzymatic digestion which results in a slower rate of digestion [2]

Thai rice is in the second rank of global rice exports. Among Thai rice, Khao Dok Mali 105 (KDML 105) is mostly consumed in Thailand because of the flavor and aroma [3]. The term Khao Dok Mali is given because of the white color and good aroma of this rice similar to jasmine flower. KDML105 is a non-glutinous rice and amylose content is around 12-17\% [4]. Riceberry (RB) rice is low amylose pigmented rice. It is a new variety that cross-bred between varieties of low amylose content and intensive purple color. After being introduced to the market, it has gained popularity due to its unique cooking qualities and fragrance of whole grain with distinctive color and delicious aftertaste while the high antioxidant content was also established. Sao Hai (SH) is high amylose white rice that is good for health. The rice texture is hard and crumbly, good for serving with curry or soup. $\mathrm{SH}$ is relatively high amylose rice compared to KDML and RB with $21.8 \%$ amylose [5]. Despite its high amylose content, it has less popularity in Thailand compare to low amylose rice.

Parboiling process is involved the partial boiling of rice paddy following with drying and milling [6]. During boiling, the gelatinization occurs only in the outer layers of aleurone part and seals the grain hence the head rice yield improved. Normally, the GI of parboiled rice is lower than normal rice whereas bioactive compounds increased [7]. On the other hand, it can give adverse effects such as reducing stickiness and enhancing brown color and rancidity in rice.

Brown rice consists of bran layer which is rich in dietary fiber, vitamins, minerals, and other health-related components when compared to the white rice [8]. The bran layer is a major source of phenolic compound in the rice grain, polishing removes this part making the grain 
less healthy [9]. The vast majority of research has focused on chronic disease prevention and control, whereby brown rice and rice bran have been shown to decrease risk of type 2 diabetes, regulate lipid metabolism, control metabolic syndrome and cardiovascular disease, and exhibit anticancer [10-12]. The objective of this research was to compare the effects of different rice processing namely parboiling and polishing on chemical properties of three major rice varieties in Thailand.

\section{Materials and Methods}

\subsection{Sample Preparation}

KDML 105, SH and RB paddy were obtained from Phrae Rice Research Center, Thailand. Paddy samples were grown in the same crop in the same year. Each variety was prepared with or without polishing and parboiling. Preparation of parboiled rice was carried out by soaking the paddy in water at $60^{\circ} \mathrm{C}$ for $1 \mathrm{~h}$. The soaked paddy was steamed at 15 Psi for 10 min. Steamed paddy was tempered for $24 \mathrm{~h}$ prior to drying at $45^{\circ} \mathrm{C}$ for $24 \mathrm{~h}$ (until moisture content was below 14\%) using hot air oven. The dried paddy was stored for 1 week prior to the milling process was conducted for 7-10 cycles (brown rice) following with polishing (white rice) using milling and polishing machine (Mitsubishi Electric type SC-KR).

\subsection{Moisture Content Analysis}

Moisture content (MC) analysis was conducted according to AOAC (2000) [13]. Sample (2-3 g) was put in pre-dried moisture can and placed in a hot air oven at $105 \pm 2^{\circ} \mathrm{C}$ for 16-18 h. Moisture content and dry matter were calculated.

\subsection{Ash Content Analysis}

The sample ( $2 \mathrm{~g}$ ) was added to well-incinerated crucibles, burned in the hot plate for $30 \mathrm{~min}$ and followed with ashed in a muffle furnace at $550^{\circ} \mathrm{C}$ for $6 \mathrm{~h} \mathrm{[13].}$

\subsection{Total Dietary Fiber Content (TDF) Analysis}

Water- and fat-free samples (1 g) was added with $20 \mathrm{~mL}$ sodium phosphate buffer $\mathrm{pH} 6.0$ and mixed. The mixture was included with $0.1 \mathrm{~mL}$ enzyme alpha-amylase (Thermamyl 120L, Sigma Aldrich) prior to incubation for $15 \mathrm{~min}$ in a shaking water bath at $100^{\circ} \mathrm{C}$. $\mathrm{HCl}$ was added to reach $\mathrm{pH}$ 1.5. To the mixture, $1 \mathrm{~mL}$ pepsin was included, and continued incubation in a shaking water bath at $40^{\circ} \mathrm{C}$ for $60 \mathrm{~min}$, then the $\mathrm{pH}$ was adjusted to 6.8 with $\mathrm{NaOH}$. Thereafter, $100 \mathrm{mg}$ pancreatin was added and re-incubated $40^{\circ} \mathrm{C}$ for $60 \mathrm{~min}$. The $\mathrm{pH}$ was adjusted to 4.5 with $\mathrm{HCl}$ and filtered with Whatman paper number 4 . The filtrate was washed twice with $10 \mathrm{~mL}$ distilled water, 10 $\mathrm{mL}$ ethanol $90 \%$ and $10 \mathrm{~mL}$ acetone, respectively and then dried at $105^{\circ} \mathrm{C}$ until constant weight (overnight) and the initial weight was recorded. Sample with Whatman paper was heated on a hot plate and put in a muffle furnace at $525^{\circ} \mathrm{C}$ for $6 \mathrm{~h}$ and weighed. The filtrate was used to analyze soluble dietary fiber. The distilled water was added to the filtrate until the volume reached $100 \mathrm{~mL}$, then added $400 \mathrm{~mL}$ of warm $95 \%$ ethanol $\left(60^{\circ} \mathrm{C}\right)$ and allowed precipitation for one night. This solution was filtered using Whatman paper number 4 and washed twice with $10 \mathrm{~mL}$ distilled water, $10 \mathrm{~mL} \mathrm{90 \%} \mathrm{ethanol} \mathrm{and} 10 \mathrm{~mL}$ acetone, respectively. Then the residue in Whatman paper was dried at $105^{\circ} \mathrm{C}$ until constant weight (overnight) and record the initial weight. Sample with Whatman paper was heated on a hot plate and put in a muffle furnace at $525^{\circ} \mathrm{C}$ for approximately $6 \mathrm{~h}$ and weighed. Finally, TDF was calculated from the summation of insoluble and soluble dietary fiber content [13].

\subsection{In vitro Starch Digestibility Analysis}

In vitro starch digestibility analysis was conducted according to Englyst et al. (1992) [14] with some modifications. Rice flour suspension (1\% wt/vol in distilled water) was heated in a water bath for 30 min until it reached $90^{\circ} \mathrm{C}$ and then cooled. The suspension $(2 \mathrm{~mL})$ was added with $3 \mathrm{~mL}$ of distilled water and $5 \mathrm{ml}$ of $0.1 \mathrm{M}$ Na-phosphate buffer pH 7.0. The mixture was incubated in a water bath at $37^{\circ} \mathrm{C}$ for $15 \mathrm{~min}$ and $5 \mathrm{~mL}$ of alpha-amylase solution was added and re-incubated at $37^{\circ} \mathrm{C}$ for $15 \mathrm{~min}$. One $\mathrm{mL}$ of the mixture was added with $2 \mathrm{~mL}$ dinitrosalicylic acid reagent, and the mixture was heated in a water bath at $100^{\circ} \mathrm{C}$ for $10 \mathrm{~min}$. After cooling, the mixture was diluted with $10 \mathrm{~mL}$ of distilled water. Absorbance was measured using a spectrophotometer with the wavelength of $520 \mathrm{~nm}$. Maltose levels of the reaction mixture were calculated using a standard curve of pure maltose. The digestibility of starch samples was calculated as a percentage relative to pure starch as follows:

$$
\text { Digestibility }=\frac{\left(\begin{array}{l}
\text { Maltose levels of sample } \\
\text { after the enzyme reaction }
\end{array}\right) \times 100}{\left(\begin{array}{l}
\text { Maltose levels of pure starch } \\
\text { after the enzyme reaction }
\end{array}\right)} \text {. }
$$

\subsection{Amylose Content Analysis}

A modified method was applied to analyze the amylose content [2]. Rice powder, $100 \mathrm{mg}$, was mixed with $1 \mathrm{~mL}$ of $95 \%$ ethanol and $9 \mathrm{~mL}$ of $1 \mathrm{M} \mathrm{NaOH}$ prior to incubation for $24 \mathrm{~h}$ at room temperature. Distilled water was added to reach the final volume of $100 \mathrm{~mL}$. One $\mathrm{mL}$ of $1 \mathrm{M}$ acetic acid and $2 \mathrm{~mL}$ iodine solution were added to $5 \mathrm{~mL}$ of sample. Distilled water was added to make up the final volume of $100 \mathrm{~mL}$. The mixture was stirred and allowed to stand for $20 \mathrm{~min}$ before absorbance was measured at $620 \mathrm{~nm}$ utilizing UV-Spectrophotometer. The amylose content of the rice samples was calculated using a standard curve plotted from the absorbance of amylose standards.

\subsection{Glycemic Index Analysis}

Glycemic index (GI) analysis was conducted according to method described by [15]. Cooked rice sample was prepared and $50 \mathrm{mg}$ of sample was added to the test tube. Pepsin (1 g) was added to $100 \mathrm{~mL} \mathrm{HCl-KCl} \mathrm{(pH} \mathrm{1.5)}$ buffer and $0.2 \mathrm{~mL}$ of the mixture was included to the test tube. The test tube was incubated at $40^{\circ} \mathrm{C}$ for $1 \mathrm{~h}$ in a shaking water bath. Tris-maleate buffer containing 2.6 UI 
$\alpha$-amylase ( $5 \mathrm{~mL}$ ) was added to sample. The samples were continued to incubation at $37^{\circ} \mathrm{C}$ in a shaking water bath. Aliquot sample $(1 \mathrm{~mL}$ ) was taken every $30 \mathrm{~min}$ (from 0 to $3 \mathrm{~h}$ ) and then placed in shaking water bath at $100^{\circ} \mathrm{C}$ for 5 min to inactivate the enzyme and refrigerated until the end of the incubation time. $3 \mathrm{~mL}$ of $0.4 \mathrm{M}$ sodium acetate buffer $\mathrm{pH} 4.75$ was added to each sample following with $60 \mu \mathrm{L}$ of amyloglucosidase. The sample was incubated in the shaking water bath for $45 \mathrm{~min}$ at $60^{\circ} \mathrm{C}$. Distilled water was added to reach $100 \mathrm{~mL}$. The aliquot was taken $(0.5$ $\mathrm{mL}$ ) and incubated with $3 \mathrm{~mL}$ of glucose GOD-POD (Glucose oxidase and Peroxidase) kit. Read absorbance using UV/VIS spectrophotometer at the wavelength of $505 \mathrm{~nm}$. Percentage of glucose at 0, 30, 60, 90, 120, 150, and $180 \mathrm{~min}$ was counted as glucose digestion rate. The curve among the time interval was established and the area below the curve was calculated as area of hydrolysis curve (AHC). The AHC of sample and standard of white bread was calculated as the hydrolysis index (HI). Finally, the GI was calculated according to the equation of $\mathrm{GI}=39.71+(0.549 * \mathrm{HI})$.

\subsection{Total Phenolic Content Analysis}

Total phenolic content (TPC) of extracts was determined by Folin Ciocalteu method as described previously [16] with some modifications. Samples were extracted according to Walter (2013) [16] by adding $3 \mathrm{~mL}$ methanol to $1 \mathrm{~g}$ sample and placed in shaking water bath $60^{\circ} \mathrm{C}$ for $20 \mathrm{~min}$. After centrifugation at $10,000 \mathrm{xg}$ for $10 \mathrm{~min}$, the supernatant was kept in freezer until analysis. Briefly, $100 \mu \mathrm{L}$ of extract was mixed with $750 \mu \mathrm{L}$ of fresh Folin-Ciocalteu reagent and incubated at room temperature for $5 \mathrm{~min}$. After that, $750 \mu \mathrm{L}$ of $6 \%(\mathrm{w} / \mathrm{v})$ sodium carbonate was added to the mixtures and allowed to completely react for $60 \mathrm{~min}$ in the dark. The absorbance was read by spectrophotometer at $756 \mathrm{~nm}$. The phenolic content was expressed as mg of gallic acid equivalent per g dry sample (mg gallic acid equivalent (GAE)/g)..

\subsection{DPPH Radical Scavenging Analysis}

The DPPH assay was conducted using Trolox as standard. The sample was extracted as described above. The extract $(50 \mu \mathrm{L})$ was mixed with $1.95 \mathrm{~mL} 60 \mu \mathrm{M}$ DPPH solution and left in the dark place for $30 \mathrm{~min}$ at room temperature. Absorbance was recorded at $517 \mathrm{~nm}$ using methanol as blank. The radical scavenging activity was expressed as mmol Trolox equivalent (TE)/g dry weight sample [17].

\subsection{Anthocyanin Content Analysis}

One $\mathrm{mL}$ of extract was added with potassium chloride buffer, $\mathrm{pH} 1$ or sodium acetate buffer $\mathrm{pH} 4.5$ to reach $10 \mathrm{~mL}$. The mixture was vortexed and absorbance was read at $510 \mathrm{~nm}$ and $700 \mathrm{~nm}$, respectively [18]. The calculation is shown below:

$$
\text { Anthocyanin (mg/g)=A x MW x DF x 1000/26,900 }
$$

$\mathrm{A}=(\mathrm{A} 510-\mathrm{A} 700) \mathrm{pH} 1$ - (A510-A700)pH4.5

MW = Molecular weight of anthocyanin (449.2)
$\mathrm{DF}=$ Dilution factor

\subsection{Statistical Analysis}

All the data were expressed as mean values. The standard deviations were analyzed and analysis of variance using SPSS for Window version 16 was carried out. Duncan's multiple range test was used to identify the difference among means at $\mathrm{p}<0.05$.

\section{Results and Discussion}

\subsection{Effect on Starch Properties}

Moisture content of all samples was not significantly different and was on its safe range of dry grain $(\leq 14 \%)$ [19] (Table 1). Ash content was higher in parboiled samples in all rice varieties. This could be due to parboiling process allows the nutrient in the rice husk to trap in the rice grain surface and pores. The result was in agreement with previous study [20] that parboiling process enhanced ash content of long grain rice up to $18 \%$. According to Chukwu and Oseh (2009) [21] parboiling process led to superior amount of iron, zinc, and calcium compared to control sample. Moreover, non-polished or brown rice had higher ash content than white rice due to high mineral content in its bran layer. Satter (2014) [22] also found that bran is a rich vitamin and mineral source such as phosphorus, potassium, iron, copper, zinc and vitamin B. Accordingly, Sangeetha (2017) [23] reported that polishing process led to a decrease of ash content more than 40\%. Among the variety, SH had the highest ash content whereas that in KDML 105 was the lowest. This could happen due to different mineral content in each rice variety.

It is apparent that amylose content of the rice grain was lower in the parboiled polished rice in all varieties. Parboiling process reduces amylose content as has been reported by Yenrina (2017) [24]. During parboiling, swelling of the rice grain occurs as a result of diffusion of water into the porous of rice grain at certain temperature and the starch becomes gelatinized, hydrogen bonds between amylose and amylopectin are disrupted [24]. Amylose content reduced because it has short chain and easy to be dissolved and leached out in water $[25,26]$. Moreover, it is believed that the lower in amylose content is because of alteration of its structure conformation [24] and bindings of amylose with lipid during parboiling process which creates resistant starch (RS) type 5 [27]. For these reasons, GI value of parboiled rice was still lower than non-parboiled rice even though the amylose content was lower (Table 1). Concerning the effect of polishing on amylose content it has also been reported that polishing led to reduction of the amylose content due to the elimination of the rice bran [28]. Among rice varieties, $\mathrm{SH}$ showed the highest amylose content as expected since it is a high amylose rice compared to other varieties inferring that without any treatment $\mathrm{SH}$ is the healthiest rice variety. It is noteworthy that parboiling process is successively reduced GI value of the low amylose rice varieties, KDML 105 and RB. 
Table 1. Starch properties of rice samples treated by different preparation process

\begin{tabular}{|c|c|c|c|c|c|c|c|c|}
\hline Rice & $\begin{array}{l}\text { Parboiling } \\
\text { Process }\end{array}$ & $\begin{array}{l}\text { Polishing } \\
\text { Process }\end{array}$ & $\begin{array}{c}\text { Moisture } \\
\text { Content (\%) }\end{array}$ & $\begin{array}{c}\text { Ash Content } \\
(\%)\end{array}$ & $\begin{array}{c}\text { Amylose } \\
\text { Content (\%) }\end{array}$ & $\begin{array}{l}\text { Total Dietary } \\
\text { Fiber (\%) }\end{array}$ & $\begin{array}{l}\text { Glycemic } \\
\text { Index (\%) }\end{array}$ & $\begin{array}{c}\text { Starch } \\
\text { Digestibility (\%) }\end{array}$ \\
\hline KDML & No & White & $13.06 \pm 0.03^{\mathrm{a}}$ & $0.61 \pm 0.03^{h}$ & $13.67 \pm 1.13^{\text {cde }}$ & $4.24 \pm 1.37^{\mathrm{d}}$ & $72.51 \pm 4.22^{\mathrm{a}}$ & $78.89 \pm 0.67^{\mathrm{a}}$ \\
\hline KDML & No & Brown & $13.22 \pm 0.08^{\mathrm{a}}$ & $1.57 \pm 0.03^{\mathrm{fg}}$ & $17.21 \pm 1.40^{\mathrm{c}}$ & $6.19 \pm 0.55^{\text {bcd }}$ & $58.42 \pm 4.22^{\mathrm{b}}$ & $60.70 \pm 1.60^{\text {cde }}$ \\
\hline KDML & Yes & White & $12.11 \pm 0.04^{\mathrm{c}}$ & $1.95 \pm 0.03^{\text {de }}$ & $12.39 \pm 0.57^{\mathrm{e}}$ & $7.43 \pm 0.00^{\mathrm{ab}}$ & $56.64 \pm 2.43^{\mathrm{bc}}$ & $73.89 \pm 6.13^{\mathrm{ab}}$ \\
\hline KDML & Yes & Brown & $11.95 \pm 0.03^{\mathrm{c}}$ & $2.41 \pm 0.20^{\mathrm{b}}$ & $15.24 \pm 2.21^{\text {cde }}$ & $8.17 \pm 1.03^{\mathrm{ab}}$ & $55.90 \pm 5.22^{\mathrm{bc}}$ & $55.98 \pm 2.40^{\mathrm{de}}$ \\
\hline $\mathrm{RB}$ & No & White & $12.65 \pm 0.16^{\mathrm{b}}$ & $0.60 \pm 0.13^{\mathrm{h}}$ & $13.09 \pm 2.84^{\mathrm{e}}$ & $3.73 \pm 0.13^{\mathrm{d}}$ & $68.19 \pm 1.18^{\mathrm{a}}$ & $73.04 \pm 6.00^{\mathrm{abc}}$ \\
\hline $\mathrm{RB}$ & No & Brown & $12.47 \pm 0.08^{\mathrm{b}}$ & $1.50 \pm 0.03^{\mathrm{g}}$ & $16.86 \pm 0.92^{\mathrm{cd}}$ & $8.40 \pm 0.35^{\mathrm{ab}}$ & $52.61 \pm 1.25^{\mathrm{bc}}$ & $52.12 \pm 5.20^{\text {def }}$ \\
\hline $\mathrm{RB}$ & Yes & White & $12.05 \pm 0.17^{\mathrm{c}}$ & $1.36 \pm 0.18^{\mathrm{g}}$ & $12.39 \pm 0.64^{\mathrm{e}}$ & $6.85 \pm 1.15^{\mathrm{abc}}$ & $54.82 \pm 1.85^{\mathrm{bc}}$ & $59.94 \pm 5.33^{\mathrm{de}}$ \\
\hline $\mathrm{RB}$ & Yes & Brown & $11.94 \pm 0.05^{\mathrm{c}}$ & $2.26 \pm 0.01^{\mathrm{bc}}$ & $13.32 \pm 0.89^{\mathrm{de}}$ & $8.44 \pm 1.10^{\mathrm{ab}}$ & $51.72 \pm 0.99^{\mathrm{bc}}$ & $39.21 \pm 10.93^{f}$ \\
\hline $\mathrm{SH}$ & No & White & $11.18 \pm 0.00^{\mathrm{d}}$ & $0.58 \pm 0.09^{h}$ & $24.36 \pm 0.69^{\mathrm{ab}}$ & $4.45 \pm 0.30^{\mathrm{cd}}$ & $58.73 \pm 2.24^{\mathrm{b}}$ & $64.94 \pm 0.93^{\mathrm{bcd}}$ \\
\hline $\mathrm{SH}$ & No & Brown & $10.92 \pm 0.06^{\mathrm{e}}$ & $1.77 \pm 0.02^{\mathrm{de}}$ & $27.41 \pm 0.18^{\mathrm{a}}$ & $4.93 \pm 0.39^{\mathrm{cd}}$ & $57.69 \pm 0.76^{\mathrm{bc}}$ & $50.61 \pm 7.33^{\text {ef }}$ \\
\hline SH & Yes & White & $11.03 \pm 0.07^{\mathrm{de}}$ & $2.14 \pm 0.11^{\mathrm{cd}}$ & $22.52 \pm 1.00^{\mathrm{b}}$ & $7.70 \pm 2.34^{\mathrm{ab}}$ & $56.29 \pm 1.87^{\mathrm{bc}}$ & $49.95 \pm 4.53^{\text {ef }}$ \\
\hline $\mathrm{SH}$ & Yes & Brown & $11.06 \pm 0.04^{\mathrm{de}}$ & $2.80 \pm 0.06^{\mathrm{a}}$ & $23.30 \pm 2.78^{\mathrm{b}}$ & $9.06 \pm 1.11^{\mathrm{a}}$ & $55.06 \pm 1.07^{\mathrm{bc}}$ & $48.16 \pm 5.46^{\mathrm{ef}}$ \\
\hline
\end{tabular}

Considering TDF value, it was found that non-polishing and parboiling process led to higher TDF values in all rice varieties (Table 1). The bran layer of rice is a rich source of dietary fiber and has been used as an additive in foods [29]. Furthermore, parboiling process alters structure conformation of starch and leads to a stronger resistant to enzymes digestion or becoming a dietary fiber [24]. Immigration of TDF from the husk, production of resistant starch type 3 and type 5 by gelatinization, retrogradation, and binding with other component are the mechanism of TDF induction by parboiling. Aside from the structure conformation, the parboiling process also increases TDF content by the fiber immigration from husk layer to the rice grain. The result indicated that pigmented rice has higher TDF than non-pigmented rice as previously reported by Shao (2014) [30]. RB had higher TDF than KDML 105 and SH in all processing. KDML 105 had the lowest TDF which led to higher starch digestibility and GI value. This means that KDML 105 is the easiest to be digested. Brown rice samples in all varieties had higher TDF than white rice according to the presence of bran layer (Table 1).

\subsection{Effect on Glycemic Index (GI) and in vitro Starch Digestibility}

Table 1 shows GI values of rice samples. It is important to note that the GI values are inversely proportional to amylose content [31]. Considering rice variety, GI of SH rice was lower than $\mathrm{RB}$ and KDML 105, respectively. It is believed to be due to the high amylose content of $\mathrm{SH}$ rice. The GI value of normal consumed rice has been reported and the value of KDML 105 was 70.3 and RB was 62 [32]. In current study, the low GI value was observed in parboiled rice. In case of the KDML 105 and RB varieties, polishing caused significant lower value of GI in the samples without parboiling process whereas that of parboiled samples, the GI values were not significant different and were lower than the non-parboiled samples.
Furthermore, in SH rice, the preparation process did not significantly alter GI values. These findings indicate that preparation process plays important role in disease prevention.

In vitro starch digestibility indicates how much the starch content can be digested by -amylase enzyme from saliva and pancreas gland. Similar to GI values, the starch digestibility was lower in parboiled samples. Moreover, brown parboiled rice had lower starch digestibility than white parboiled rice. This infers that parboiled brown rice is harder to digest or need longer time to digest [30]. In brown rice, this could happen due to increase of the dietary fiber content whereas parboiling causes change in the structure of starch, diffusion and adhesion of rice bran and husk component [33]. Retrogradation that occurs after parboiling led to changes in the amorphous state of starch granules to a crystalline state. This crystallized starch form can resist enzymatic degradation in the small intestine for up to three hours and spontaneously lower the concentration of digestible starch in cooked rice [34]. B-type starch has a structure of double helices with hexagonal unit cell which is harder to be digested compared to A-type starch that has monocyclic unit cell [35]. It has been reported that retrogradation occurred after parboiling led to construction of B-type starch granules [36]. KDML 105 was the most digestible rice variety compared to $\mathrm{SH}$ and $\mathrm{RB}$ while non-parboiled $\mathrm{RB}$ showed high percentage of starch digestibility. SH had low digestible and high in resistant starch due to the native resistant starch type 1 (RS1) and type 2 (RS2) in SH cultivar. The rate of digestion depends on granule size, the amylose-amylopectin ratio, starch protein interaction, amylose-lipid complexes, and level of resistant starch. Soaking and steaming during parboiling process resulted in dispersion of fiber in embryo and aleurone layer into the endosperm. This condition causes lowering of the starch digestibility as has been reported that fiber content in the rice led to the lower digestibility of the starch [24]. 
Table 2. Antioxidant content and antioxidant activity of rice samples treated with different preparation process

\begin{tabular}{cccccc}
\hline Rice & Parboiling Process & PolishingProcess & Anthocyanin (mg/g) & $\begin{array}{c}\text { TPC } \\
(\mathbf{m g ~ G A E} / \mathbf{g})\end{array}$ & $\begin{array}{c}\text { DPPH } \\
(\mathbf{m m o l ~ T E} / \mathbf{g})\end{array}$ \\
\hline KDML & No & White & ND & $0.36 \pm 0.01^{\mathrm{g}}$ & $2.32 \pm 0.00^{\mathrm{g}}$ \\
KDML & No & Brown & ND & $0.99 \pm 0.00^{\text {cde }}$ & $2.49 \pm 0.03^{\mathrm{cd}^{\mathrm{cd}}}$ \\
KDML & Yes & White & ND & $0.81 \pm 0.22^{\text {def }}$ & $2.44 \pm 0.03^{\text {de }}$ \\
KDML & Yes & Brown & ND & $1.31 \pm 0.23^{\mathrm{bc}}$ & $2.55 \pm 0.06^{\mathrm{bc}}$ \\
RB & No & White & $0.03 \pm 0.02^{\mathrm{c}}$ & $0.43 \pm 0.08^{\mathrm{fg}}$ & $2.25 \pm 0.02^{\mathrm{h}}$ \\
RB & No & Brown & $0.24 \pm 0.05^{\mathrm{b}}$ & $1.56 \pm 0.5^{\mathrm{ab}}$ & $2.48 \pm 0.02^{\mathrm{d}}$ \\
RB & Yes & White & $0.05 \pm 0.02^{\mathrm{c}}$ & $1.32 \pm 0.16^{\mathrm{bc}}$ & $2.41 \pm 0.00^{\mathrm{ef}}$ \\
RB & Yes & Brown & $0.60 \pm 0.03^{\mathrm{a}}$ & $1.93 \pm 0.16^{\mathrm{a}}$ & $2.55 \pm 0.04^{\mathrm{bc}}$ \\
SH & No & White & ND & $0.29 \pm 0.05^{\mathrm{g}}$ & $2.37 \pm 0.01^{\mathrm{fg}}$ \\
SH & No & Brown & ND & $1.04 \pm 0.00^{\mathrm{cd}}$ & $2.68 \pm 0.03^{\mathrm{a}}$ \\
SH & Yes & White & ND & $0.57 \pm 0.07^{\mathrm{efg}}$ & $2.45 \pm 0.02^{\mathrm{de}}$ \\
SH & Yes & Brown & ND & $1.58 \pm 0.00^{\mathrm{ab}}$ & $2.61 \pm 0.01^{\mathrm{b}}$ \\
\hline
\end{tabular}

Note: ND = Not detectable.

\subsection{Effect on Antioxidant Content and Activity}

Table 2 shows that TAC in RB was higher in non-polished samples and the effect was more pronounce in parboiling treatment. This result confirms that rice bran is the source of anthocyanin in $\mathrm{RB}$ as has been reported previously [37]. Similarly, the highest TPC content was also observed in RB. Considering processing, the brown rice had superior content of TPC than white rice both in pigmented and non-pigmented rice. As found in the work reported by [38] that polishing reduced significantly the content of phenolic content. According to Shao (2014) [30], DPPH value and TPC content in rice were found at the highest level in the bran layer followed by embryo, whole grain, and endosperm, respectively. Non-parboiled and parboiled white SH had lower TPC than KDML 105 but those in brown $\mathrm{SH}$ with or without parboiling process were higher than KDML 105 in the same treatment. It was discernible that parboiling increased TPC content. This is because parboiling process enhances absorption of bioactive compounds from the husk, embryo, and bran layer to the rice grain [39]. Antioxidant activity determined using DPPH assay showed that DPPH values were similar in all treatments which ranged between 2.33-2.68 mmol TE/g. However, the highest antioxidant activity was found in non-parboiled brown $\mathrm{SH}$ and the lowest valued obtained in non-parboiled white RB. These results imply that the bioactive compound content in rice can be reduced from milling and parboiling process because the bran was erased during milling and also leaching out of the compounds occurred during the parboiling process. High DPPH value was found in parboiled brown process for each variety but the highest DPPH was found in non-parboiled brown SH rice. This finding is also similar with Muntana and Prasong (2010) [40] who found that the highest antioxidant activity was observed in non-pigmented Thai rice compared to pigmented rice.

\section{Conclusion}

Rice variety and processing influenced chemical characteristics of rice. Parboiled brown RB showed high ash content which represented high mineral content. This rice also showed the highest dietary fiber, antioxidants, anthocyanin and TPC content and the lowest starch digestibility which supported its low glycemic index. This infers that parboiled brown RB is advantageous to diabetic consumers as well as beneficial for reducing disease risk to all consumers.

\section{Acknowledgements}

Authors would like to thank Mae Fah Luang University for financial support and technical assistance.

\section{References}

[1] Muraki, I., Wu, H., Imamura, F., Laden, F., Rimm, B. E., Hu, B. F., Willet C.W. and Sun, Q, "Rice consumption and risk of cardiovascular disease: results from a pooled analysis of 3 U.S. cohorts,” The American Journal of Clinical Nutrition, 101(1). 164-72. 2014

[2] Jeevetha, S., Barakatun-Nisak, M. Y., Ngan, H-B, Ismail, A. and Azlan, A, "Relationship between Amylose Content and Glycemic Index of Commonly Consumed White Rice," IOSR Journal of Agriculture and Veterinary Science, 7 (9). 12-18. 2014.

[3] Tulyathan, V. and Leeharatanaluk, B., "Changes in quality of rice (Oriza sativa L.) CV. Dawk Mali 105 during storage,” Journal of Food Biochemistry, 31. 415-425. 2007.

[4] Kongseree, N, “Overview Rice Grain Quality in Thailand” 2008. [Online] Available: https://www.google.co.th/search?q=ngamchuen+rice+quality\&ie= utf-8\&oe=utf-8\&gws_rd=cr\&ei=cfQoVTGEZS0uQTW5baoDw\#.[Accessed May. 01, 2018].

[5] Okonogi, S., Kaewpinta, A., Khongkhunthian, S. and Yotsawimonwat, $\mathrm{S}$, "Effect of rice variety on the physicochemical properties of the modified rice powders and their derived mucoadhesive gels," Drug Discoveries \& Therapeutics, 9(3).221-228. 2015. 
[6] Bhattacharya, K. R, Parboiling of rice: Rice chemistry and technology, AACC International, Bangkok, 2004, 329-404.

[7] Boers, H. M., Seijen, . H. J. and Mela, D. J, “A systematic review of the influence of rice characteristics and processing methods on postprandial glycaemic and insulinaemic responses," British Journal of Nutrition, 114 (7). 1035-1045. 2015.

[8] Bergman, C., Chen, M. H., Delgado, J. and Gipson, N, "Rice grain quality,” USDA-ARS-Rice Research Unit Rice Quality Program. [Online] Available:

https://beaumont.tamu.edu/RiceContestStudyGuide/.../Rice\%20 Grain\%20Quality.pdf. [Accessed April.29, 2018].

[9] Shree, P., Kumar, M. and Singh, D. K, "Evaluation of tota phenolic content and antioxidative properties of unpolished and polished black, red and brown rice varieties from India," Journal of Agricultural Engineering and Food Technology, 4(2). 113-117. 2017.

[10] Cheng, H.H., Huang, H.Y., Chen, Y.Y., Huang, C.L., Chang, C.J., Chen, H.L. and Lai, M.H, "Ameliorative effects of stabilized rice bran on type 2 diabetes patients," Annals of Nutrition and Metabolism, 56(1). 45-51. 2010.

[11] Cicero, A.F., Derosa, G, "Rice bran and its main components: potential role in the management of coronary risk factors," Current Topics in Nutraceutical Research, 3(1). 29-46. 2005.

[12] Henderson, A.J., Ollila, C.A., Kumar, A., Borresen, E.C., Raina, K., Agarwal, R. and Ryan, E.P, "Chemopreventive Properties of Dietary Rice Bran: Current Status and Future Prospects” Advances in Nutrition, 3(5). 643-53. 2012.

[13] AOAC. Official method of analysis (17th ed.). Gaithersburg, MD, USA: Association of Official Analytical Chemists. 2000.

[14] Englyst, H.N., Kingman, S.M. and Cummings J.H, "Classification and measurement of nutritionally important starch fractions," European Journal of Clinical Nutrition, 46. S33-S50. 1992.

[15] Leoro, M.G.V., Clerici, M.T.P.S.,Chang, Y.K. and Steel, C.J, "Evaluation of the in vitro glycemic index of a fiber-rich extruded breakfast cereal produced with organic passion fruit fiber and corn flour," Ciência e Tecnologia de Alimentos, 30(4). 964-968. 2010.

[16] Materska, M. and Perucka, I, “Antioxidant activity of the main phenolic compounds Isolated from Hot pepperfruit (Capsicum annuum L," Journal of Agriculture and Food Chemistry, 53(5). 1750-6. 2005.

[17] Molyneux, P, "The use of the stable free radical diphenylpicrylhydrazyl (DPPH) for estimating antioxidant activity songklanakarin,” Journal of Science and Technology, 26(2). 211-219. 2004.

[18] Laokuldilok, T., Surawang, S. and Klinhom, J, "Influence of milling time on the nutritional composition and antioxidant content of Thai rice bran,” Food and Applied Bioscience Journal. 1(3). 112-130. 2013

[19] IRRI (International Rice Research Institute), “Rice Milling," [Online] Available: http://www.knowledgebank.irri.org/index. php?option=com zoo\& task=item\&item_id=1133\&Itemid=822. 2013. [Accessed May. 02, 2018]

[20] Heinemann, R. J. B., Fagundes, P. L., Pinto, E. A., Penteado, M. V. C. and Lanfer-marquez, U. M, "Comparative study of nutrient composition of commercial brown, parboiled, and milled rice from Brazil,” Journal Food Composition and Analysis, 18. 287-96. 2005.

[21] Chukwu, O., and Oseh, F. J, "Response of nutritional contents of rice (Oryza sativa) to parboiling temperatures" American-eurasian Journal of Sustainable Agriculture, 3(3). 381-387. 2009.

[22] Satter, M. A., Ara, H., Jabin, S. A., Abedin, N. and Ara, U, "Nutritional composition and stabilization of local variety rice bran BRRI-28," International Journal of Science and Technology, 3(6). 306-313. 2014.

[23] Sangeetha, N, "Determination of nutritional composition of different rice bran," World Journal of Pharmacy and Pharmaceutical Sciences, 6(5). 691-700. 2017.
[24] Yenrina, R., Ismanto, S. D. and Ummah, R, “The changes on dietary fiber and starch digestibility of various rice varieties from West Sumatera through parboiling process,” Research Journal of Pharmaceutical, Biological and Chemical Sciences, 8(2). 929-935. 2017.

[25] Derycke, C., Vandeputte, G.E., Vermeylen, R., De, M. W. Goderis, B., Koch M.H.J. and Delcour, J.A, "Starch gelatinization and amylose-lipid interactions during rice parboiling investigated by temperature resolved wide angle X-ray scattering and differential scanning calorimetry,” Journal of Cereal Science, 42 . 334-43. 2007

[26] Kale, S. J., Jha, S. K., Jha, G. K., Sinha, J. P. and Lal, S. B, "Soaking Induced Changes in Chemical Composition, Glycemic Index and Starch Characteristics of Basmati Rice” Journal of Rice Science, 22(5). 227-236. 201).

[27] Ordonio, R. L. and Matsuoka, M, "Increasing resistant starch content in rice for better consumer health," Proceedings of the National Academy of Sciences, 113(45). 12616-12618. 2016.

[28] Musa, A.S.N., Umar, I. M. and Ismail, M, "Physicochemical properties of germinated brown rice (Oryza sativa L.) starch,” African Journal of Biotechnology, 10 (33). 6281-6291. 2011.

[29] Sekhon, K.S., Dhillon, S.S., Singh, N., Singh, B, "Functional suitability of commercially milled rice bran in India for use in different food products," Plant foods for human nutrition, 50: 127-140. 1997.

[30] Shao, Y., Xu, F., Sun, X., Bao, J. and Beta, T, “Identification and quantification of phenolic acids and anthocyanins as antioxidants in bran, embryo and endosperm of white, red and black rice kernels (Oryza sativa L.),” Journal of Cereal Science, 59. 211-218. 2014.

[31] Jain, A., Rao, S. M., Sethi, S., Ramesh, A. and Kalaichelvani, C, "Effect of cooking on amylose content of rice," European Journal of Experimental Biology, 2 (2).385-388. 2012.

[32] Jaisut, D. and Soponronnarit, S, "Changes in the physical and chemical properties of thai brown rice caused by high-temperature treatment," Journal of Developments in Sustainable Agriculture, 7. 33-38. 2012.

[33] Widowati, S., Santosa, S., Astawan, M, and Akhyar, "Reducing glycemic index of some rice varieties using parboiling process," Indonesian Journal of Agriculture, 3(2). 104-111. 2010.

[34] Lu, L.W., Venn, B., Lu, J., Monro, J. and Rush, E, "Effect of cold storage and reheating of parboiled rice on postprandial glycaemic response, satiety, palatability and chewed particle size distribution," Journal of Nutrients, 9 (275). 2017.

[35] Perez, S. and Bertoft, E, "The molecular structures of starch components and their contribution to the architecture of starch granules: A comprehensive review,” Starch Journal, 62. 389-420. 2010.

[36] Deepa, G., Singh, V. and Naidu, A, “A comparative study on starch digestibility, glycemic index and resistant starch of pigmented ('Njavara' and 'Jyothi') and a non-pigmented ('IR 64') rice varieties," Journal of Food Science Technology, 47(6). 644-649. 2010.

[37] Chinprahast, N., Tungsomboon, T. and Nagao, P, “Antioxidant activities of Thai pigmented rice cultivars and application in sunflower oil," International Journal of Food Science and Technology, 51.46-53. 2016.

[38] Walter, M., Marchesan, E., Massoni, P. F. S., da Silva, L. P., Sartori, G. M. S. and Ferreira, R. B, "Antioxidant properties of rice grains with light brown, red and black pericarp colors and the effect of processing,” Food research international, 50(2). 698-703. 2013.

[39] Hu, Z., Tang, X., Liu, J., Zhu, Z. and Shao, Y, "Effect of parboiling on phytochemical content, antioxidant activity and physicochemical properties of germinated red rice," Food Chemistry, 214. 285-292. 2017.

[40] Muntana, N. and Prashong, S, "Study on total phenolic contents and their antioxidant activities of thai white, red and black rice bran extracts,” Pakistan Journal of Biological Sciences, 13 (4). 170-174. 2010. 